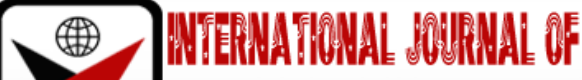 בालिक
}

ISSN 2278-0211 (Online)

\section{Compliance to Waste Management Policy Guidelines in Abia State, South-east, Nigeria}

\author{
Dr. Ijeoma Nduka \\ Associate Professor, Department of Community Medicine, Abia State University, Nigeria
}

\begin{abstract}
:
Indiscriminate waste disposal practices can result in numerous health hazards, unsightliness and offensive odour in the environment. Government is responsible for policy formulation and enforcing policy implementation for the benefits of its citizens. Residents are also expected to obey government policies and take responsibilities in handling and disposal of waste they generate. This study was therefore carried out to determine compliance of residents of Umuahia, Abia state to waste management policies. This was a descriptive cross-sectional study carried out amongst residents in Umuahia, Abia state from January to March 2021. Cluster sampling technique was used to select households while simple random sampling was used to select respondents from each of the 384 households that participated in the study. Data was collected by the use of interviewer administered and self-administered questionnaires. Data was analysed using SPSS Vs 23.0 and presented in tables. A P $<0.05$ was taken to be statistically significant. Majority of the respondents $217(56.5 \%)$ rated themselves as non-compliant to government waste management policies. Only 3.9\% of respondents comply with government policy on waste management. There were adequate awareness responses on waste management policies among respondents. Three hundred and eleven respondents(81.0\%) were aware of the policy, 281(73.2\%) were aware of penalties to offenders. Only 13(3.4\%) respondents segregate their waste while $77(20.1 \%)$ bag their waste. There was a statistical significant difference between risk perception to hazards of improper waste management and compliance to government waste management policy.
\end{abstract}

Keywords: Waste management, Policy, Compliance, Abia State

\section{Introduction}

Nigeria battles with waste management as documented by researchers in different parts of the country (Olufunmilayo, et al 2019;Maduabuchi, 2018;ImohUkpong\& Emmanuel Udofia 2011). Piles of trash are seen littered on streets, in gutters, around houses and any unoccupied lands or premises. These wastes are generated from homes, markets, schools, hospitals, churches, industries, business and commercial places. Economic growth and urbanisation affectwaste generation in many parts of world (Hoornweg\&Perinaz, 2012).Increased waste generated from man's daily activities add substantial quantities of hazardous substances to the environment and have potential health and environmental consequences (Slack \& Voulvoulis,2005;Blundell,2004).Improper waste management is a public health issue requiring attention of government and citizens to handle. The environment is constantly defaced, degraded and threatened by adverse effects of these harmful substances contained in waste. Waste handling and disposal is everybody's business; however, the government draws a roadmap for its citizens to follow. Every society is governed by policies and laws to regulate interactions of man and the environment. Governments are responsible for setting laws and policies to guide activities in society including those of waste management. Nigeria has well-established laws to address waste handling and disposal. Nigeria's constitution empowers the federal government to protect and improve the environment, safeguard water, air and land, forest and wildlife of Nigeria (Oghogho\&Temitayo, (2011). This is enforced by the Federal Ministry of Environment. Nigeria has three policy guidelines on waste management and sanitation (FMOE, 2014); the National Policy guidelines on Solid Waste Managementwhich is meant to 'improve and safeguard public health and welfare through efficient Solid Waste Management methods that will be economical, sustainable and guarantee sound environmental health. The National Policy Guidelines on Sanitary Inspection of Premises which aims at promoting clean and healthy environment for the populace. Lastly, the National Environmental Sanitation Policy aimed at promoting and strengthening all government regulations concerned with housing and urban development. It also addresses sanitation related endemic diseases and illnesses and environmental education. Included in the guidelines are punishments for offenders such as payment of a certain amount as fine, or imprisonment, or both. States in Nigeria are responsible for setting up their own policy and guidelines within the context of the federal constitution. According to Abia State Basic Environmental Law of (2004), household waste management is the responsibility of Ministry of Environment and Solid Mineral Resources, the state's Environmental Protection Agency, and the local government authorities. The guideline stipulates processes from waste generation to final disposal. The law prohibits indiscriminate dumping of refuse in streets, 
open spaces and drains. The law mandates landlords and tenants to manage waste around their premises while the state government is expected to provide designated sites for refuse disposal all over the state. There are also stipulated punishments for offenders of waste management laws in the state. In spite of the clearly defined waste management policy guidelines in the state, the level of compliance of residents is very poor (Maduabuchi,2018; Egesi et al, 2016; Ezerieet al,2017; Nduka et al 2013). Refuse is visibly seen on streets of major cities in Abia. The most common is open dumping on the roads neglecting government's designated spaces for waste disposal. Waste management involves the collection, transportation, processing, recycling or disposal of waste materials produced by human activities. This process is aimed at reducing the potential health effects associated with waste generation (USEPA,2014).Role of government and residents in keeping to existing waste management guidelines will halt degradation of the environment from indiscriminate dumping of refuse. Waste handling and disposal is everybody's responsibility in ensuring the environment is protected and restored from further damage. This can be achieved through proper planning backed by workable policies and law (Johanna et al, 2017; Amit, 2017).Compliance to waste management is multifaceted (Shehu, et al, 2018; DeGroff, \&Cargo,2009; Warren, 2014) and difficult in developing countries with observed constraints of lack of clear policy assigning responsibilities, poor environmental perception, and inappropriate institutional framework, weak and poorly enforced environmental laws, and inadequate professional manpower/research activities(Habiruet al, 2017). Studies on waste handling and disposal have been conducted in the past, however, few relating to compliance of residents to waste management guidelines and associated factors are available especially in Abia state. Thus, this study examines the compliance of residents in Abia State to waste management policy guidelines and factors influencing compliance.

\section{Materials and Methods}

\subsection{Study Area}

This study was conducted in Umuahia, Abia state. Umuahia is Abia state's capital. Abia is a state in the south eastern part of Nigeria. It is located along the rail road that lies between Port Hartcourt to its south and Enugu to its north. Umuahia has a population of 359,230 according to 2006 census. ${ }^{20}$ The language in Umuahia is predominantly Igbo. Residents of Umuahia are a mix of civil servants, traders, businesses and farmers. Umuahia has two major seasons in the year- raining and dry season. The raining season ushers in agricultural activities and at this time, there is usually increase in waste generation from various activities.

\subsection{Study Population}

The study was carried out amongst households in Umuahia, the capital of Abia State. Only respondents who were at least $15 y e a r s$ and responsible for emptying waste were included in the study.

\subsection{Study Design and Period}

This was a descriptive cross-sectional study conducted from January to March, 2021 to determine compliance to waste management policies and guidelines by residents in Abia state.

\subsection{Sample Size Determination}

Single population proportion formula was used to calculate the sample size. Using an assumption of $50 \%$ proportion of residents compliant to Abia state waste management policies and laws. The formula was substituted based on $95 \%$ confidence interval $(Z=1.96)$, and $5 \%$ error margin.

Therefore, $n=Z^{2} p(1-P) / d^{2}$

$=\left(1.96^{2}\right) \times 0.5(1-0.5) / 0.05^{2}=384$

\subsection{Sampling}

Cluster sampling technique was used to group the households into clusters. A total of 384 households were selected from the clusters using simple random sampling technique. One respondent from each household who was at least 15years of age and responsible for regular disposal of waste.

\subsection{Data Collection}

Semi-structured questionnaire was used for data collection. The researchers administered the questions to respondents who could not read - interviewer administered and self-administered for those who could read and understand. Information on socio-demographics, waste segregation and bagging were obtained from the respondents. The respondents were asked of their awareness of the state's waste management policies and penalties to offenders. On a scale of 0-3 (0-not compliant, 1- poor compliance, 2- moderate compliance and 3-very compliant), the respondents were asked to rate themselves on compliance to Abia State waste management policies and guidelines. The respondents were also asked about their perception of being at risk of exposure to harmful substances contained in waste as a result of improper waste disposal practices.

\subsection{Data Analysis}

Data collected was analysed using SPSS software version 21.0. Data was presented in frequency tables. Inferential statistics was used to test association between categorical variables. P-value of $<0.05$ was taken to be statistically significant. 


\subsection{Ethical Clearance}

Ethical clearance for the study was obtained from the research and ethics committee of Abia State University Teaching Hospital. The aim and objectives of the study were explained to the participants and informed consent obtained before commencement of study.

\section{Results}

A total of 384 respondents from each household were interviewed. Table 1 shows socio-demographic characteristics of respondents. Majority of the respondents (33\%) were in 19-23years age group while only 4(1\%) respondents were above 38years. The predominant gender was female with over $80 \%$ belonging to this group. One hundred and ninety-one respondents (49.7\%) had a family size of 3-6 while only $11(2.9 \%)$ of the respondents had a family size of more than 10. Majority of the respondents, $243(63.3 \%)$ had secondary school education.

\begin{tabular}{|c|c|c|}
\hline Variable & Frequency & Percentage (\%) \\
\hline \multicolumn{3}{|l|}{ Age (years) } \\
\hline $15-18$ & 105 & 27.3 \\
\hline $19-23$ & 127 & 33.0 \\
\hline $24-28$ & 63 & 16.4 \\
\hline $29-33$ & 57 & 15.0 \\
\hline $34-38$ & 28 & 7.3 \\
\hline$>38$ & 4 & 1.0 \\
\hline Total & 384 & 100 \\
\hline \multicolumn{3}{|l|}{ Sex } \\
\hline Male & 74 & 19.3 \\
\hline Female & 310 & 80.7 \\
\hline Total & 384 & 100 \\
\hline \multicolumn{3}{|l|}{ Family size } \\
\hline 2 & 59 & 15.4 \\
\hline $3-6$ & 191 & 49.7 \\
\hline $7-10$ & 123 & 32.0 \\
\hline$>10$ & 11 & 2.9 \\
\hline Total & 384 & 100 \\
\hline \multicolumn{3}{|c|}{ Educational status } \\
\hline None & 10 & 2.6 \\
\hline Primary & 78 & 20.3 \\
\hline Secondary & 243 & 63.3 \\
\hline Tertiary & 53 & 13.8 \\
\hline Total & 384 & 100 \\
\hline
\end{tabular}

Table 1: Socio-Demographic Characteristics of Respondents

Table 2 shows responses on waste segregation and bagging. Three hundred and seventy-one (96.6\%) respondents do not segregate their waste, only 77 (20.1\%) respondents bag their waste while 307 (79.9\%) do not bag their waste. One hundred and eighty-nine (49.2\%) respondents use buckets to package their waste.

\begin{tabular}{|c|c|c|}
\hline Variable & Frequency & Percentage (\%) \\
\hline Do you segregate your waste & & 3.4 \\
\hline Yes & 13 & 96.6 \\
\hline No & 371 & 100 \\
\hline Total & 384 & 20.1 \\
\hline Do you bag your waste & & 79.9 \\
\hline Yes & 77 & 100 \\
\hline No & 307 & 49.2 \\
\hline Total & 384 & 20.1 \\
\hline How do you package your waste & & 30.7 \\
\hline Buckets & 189 & 100 \\
\hline Bags & 77 & \\
\hline Wheel barrows & 118 & \\
\hline Total & 384 & \\
\hline
\end{tabular}

Table 2: Waste Segregation and Bagging 
Table 3 shows awareness of waste management policy guidelines by respondents. Three hundred and eleven $(81.0 \%)$ respondents, were aware of the state's waste management policy.

\begin{tabular}{|c|c|c|}
\hline Variable & Frequency & Percentage (\%) \\
\hline $\begin{array}{c}\text { Are you aware of the state's waste } \\
\text { management policy }\end{array}$ & & \\
\hline Yes & 311 & 81.0 \\
\hline No & 73 & 19.0 \\
\hline Total & 384 & 100 \\
\hline
\end{tabular}

Table 3: Awareness of Waste Management Policy Guidelines in the State

Table 4 shows awareness of penalties for offenders who violate the state's waste management policy. Penalties respondents were aware of included payment of fines, 281(73.2\%) and charge offender to court, 127 (33.1\%).

\begin{tabular}{|c|c|c|}
\hline Variable & Frequency & Percentage (\%) \\
\hline Are you aware of any penalties to offenders of the law on waste & & \\
management & & \\
\hline Yes & 281 & 73.2 \\
No & 103 & 26.8 \\
Total & 384 & 100 \\
\hline *Types of penalties & 281 & 73.2 \\
\hline Payment of fine & 127 & 33.1 \\
\hline Charged to court & 103 & 26.8 \\
\hline I don't know & & \\
\hline
\end{tabular}

\section{Table 4: Penalties to Offenders}

*Multiple Responses

Table 5 shows respondents' rating of their compliance to waste management policy on a scale of $0-3$. Majority of the respondents, $217(56.5 \%)$ rated 0 to compliance while only 15 (3.9\%) rated themselves 3 on compliance.

\begin{tabular}{|c|c|c|}
\hline Variable & Frequency & Percentage (\%) \\
\hline Scale & & 56.5 \\
\hline 0 & 217 & 20.8 \\
\hline 1 & 80 & 18.8 \\
\hline 2 & 72 & 3.9 \\
\hline 3 & 15 & 100 \\
\hline Total & 384 & \\
\hline
\end{tabular}

Table 5: Rating of Compliance to Waste Management Policy and Guidelines

Table 6 shows respondents' perception of their exposure risk from improper waste disposal. More than half, 209 $(54.4 \%)$ respondents perceived themselves as been at risk of exposure to waste hazards.

\begin{tabular}{|c|c|c|}
\hline Variable & Frequency & Percentage (\%) \\
\hline $\begin{array}{c}\text { Do you see yourself at risk of exposure to } \\
\text { waste hazards }\end{array}$ & & \\
\hline Yes & 209 & 54.4 \\
\hline No & 175 & 45.6 \\
\hline Total & 384 & 100 \\
\hline
\end{tabular}

Table 6: Risk Perception from Improper Waste Disposal

Table 7 shows the association between risk perception and compliance to waste management policy. The association was statistically significant with $\mathrm{P}<0.001$

\begin{tabular}{|c|c|c|c|c|}
\hline Variable & Frequency (\%) & & & \\
\hline Compliance rating & Risk perception & & & \\
\hline & Yes & No & Total & $\mathrm{X}^{2} / \mathrm{P}$-value \\
\hline 0 & $92(42.4)$ & $125(57.6)$ & 217 & \\
\hline 1 & $42(52.5)$ & $38(47.5)$ & 80 & $\mathrm{X}^{2}=48.32$ \\
\hline 2 & $63(87.5)$ & $9(12.5)$ & 72 & $\mathrm{P}=<0.001$ \\
\hline 3 & $12(80.0)$ & $3(20.0)$ & 15 & \\
\hline Total & 209 & 175 & 384 & \\
\hline
\end{tabular}

Table 7: Association between Risk Perception and Compliance Rating 


\section{Discussion}

This study showed low compliance to waste management guidelines in Umuahia, Abia state. This result is similar to a study carried out in Umuahia in 2016 (Egesi etal, 2016). The report showed that waste segregation at source was not a popular practice in the town. Waste segregation at source reduces the final volume requiring collection and disposal (Imam, 2018). From the 2016 study report (Egesi et al, 2016) conducted in Umuahia, there seems to be no improvement in waste disposal practices amongst residents as at the time this study was conducted. Waste was seen littered all over streets of the state capital, Umuahia as was reported in a previous study (Egesi et al, 2016).This study revealed a statistically significant difference between risk perception of hazards exposure from improper waste management and compliance to Government guidelines on waste management. This was similar to previous studies carried out in Nigeria (Adekola et al, 2021; Awosan et al, 2017).Despite fair knowledge of risk perception of improper waste disposal among respondents in this study; there was poor compliance to Government's directive on waste management. This might be as a result of the age of persons responsible for waste disposal in households. This study showed that children 15-18years were responsible in some homes for disposal of refuse. Perhaps this could be one of the reasons for failure of implementation of waste management laws. There might possibly be need to formulate a policy abolishing certain age from disposal of refuse.

Poor compliance to waste management guidelines in Nigeria have been documented to be a combination of certain factors associated with poor funding, people's attitude and beliefs (Agunwamba, J.C. 1998). Though this study did not conduct an economic analysis of waste management, it could be inferred that a lack of adequate funding for any project has huge effects on its implementation. Future studies could be done to analyse funding sources and challenges of waste management in Nigeria. A right attitude and belief may positively influence compliance to waste generation and disposal. According to Schubeler, et al, (1996), positive attitudes are built through awareness campaigns and educational measures on negative impacts of inadequate waste collection and disposal. Information on citizens' rights to waste management services and their responsibilities as waste generators should form a major topic of this public awareness campaign. Awareness of waste management laws was encouraging among respondents in this study. However, it is important to consider the level of awareness and what they do know regarding implications of improper waste management. This will help in development of education materials during awareness programmes. Factors beyond just awareness of the law and punishment to offenders might be responsible for poor compliance. A study conducted in Nigeria (Benefit \& Samuel (2012) revealed causes of poor waste management and policy implementation as ignorance, weak government regulation and legislation and no clear delineation of responsibilities on waste management. Weak government regulations empower citizens to disobey laws. Government at every level makes laws, enforces its implementation and monitors progress and outcomes. The report noted also the lack of public education and poor environmental education while proffering recommendations of engaging communities in waste management. Funding is a major issue in waste management. In Abia state, funding is required to maintain the vehicles that evacuate waste and no fewer than two waste vehicles are required at every dump site for efficient waste collection and evacuation. Inadequate attention to challenges of agencies responsible for handling waste, will result in low morale of workers, thereby affecting the collection and disposal of waste (Ogwueleka 2009). A tour of the study area during data collection showed indiscriminate dumping of waste; the researchers felt the dump sites were not appropriately sited. This observation was similar to a study report in Maiduguri, Nigeria (Dauda\&Osita, 2003) where inappropriate siting, design, operations and maintenance of dumps, inadequate onsite storage facilities and landfills hindered adequate waste disposal. It is therefore, imperative that government employ persons with the right expertise to manage waste. Regular breakdown of waste collection trucks poses a major challenge in waste management (Ogwueleka 2009). This has been attributed to the deplorable state of roads in Nigeria and slum settlements which makes it difficult for compactor trucks to navigate such localities. Thus, better road networks and regular maintenance of waste collector trucks will enhance proper and timely waste evacuation from dump sites.

Abia state is among the fast-growing economies in Nigeria and therefore its expected that waste generation from man's daily activities will be huge. It becomes a serious public health problem when waste management policies are not implemented and monitored. Indiscriminate disposal of waste is harmful to communities affecting health and aesthetics. According to the World Health Organisation (2019), over 1.3 to 4.0 million cases of cholera and 21000 to 143000 deaths worldwide are reported annually due to challenges of waste handling and disposal. Despite the knowledge of waste hazards amongst respondents in this study, compliance to waste management policies is still a problem in Abia state. Quantity and rate of waste generation appears to have overwhelmed government's efforts. Individuals in the state should rise up to the challenge and support government in ensuring waste are cleared off roads and other inappropriate dump sites while government should enforce waste management policies and sanitation laws.

\section{Study Limitations}

This study was based on only quantitative data collection from residents in the study area. Inclusion of government agencies responsible for waste handing might further strengthen result. Also being a cross-sectional study, a cause-effect relationship might be difficult to determine.

\section{Conclusion}

This study showed non-compliance to waste management policies by residents in Abia state. Though respondents showed adequate knowledge on hazards associated with improper waste disposal, there seems to be other reasons for non-compliance other than just knowledge. This might be linked to lack of waste management policy enforcement by government. Government needs to invest and develop waste recycling as a means of revenue generation for the state. 


\section{Recommendations}

The following are recommended from this study

- Government should enforce waste management policies in the state

- Government should develop policies on waste minimisation, reuse and recycle

- Government should partner communities in waste disposal

- Government should allocate more resources to waste management

- Skilled personnel should be engaged in waste handling and disposal in the state

- Public awareness campaigns on impact of improper waste disposal should be promoted by the state government.

\section{References}

i. Abia State Basic Environmental Law (2004):7

ii. Adekola, P.O., Iyalomhe, F.O., Paczoski, A. (2021). Public perception and awareness of waste management from Benin City.Sci Rep, 11:306

iii. Agunwamba, J.C. (1998). Solid Waste Management in Nigeria: Problems and Issues'.Environmental Management, 22(6):849-856.

iv. Amit J. (2017). Summary Report: Waste Management in Asian Countries. United Nations Environment Programme, Asian Institute of Technology Regional Resource Centre for Asian and the Pacific.

v. Awosan K., Oche M.O., Yunusa E.U., Mansur R. (2017). Knowledge. Risk Perception and Practices Regarding the Hazards of Unsanitary Solid Waste Disposal among Small-Scale Business Operators in Sokoto, Nigeria. International Journal of Tropical Disease \& Health, 26(2):1-10.

vi. Benefit 0. \& Samuel E. (2012). Solid waste management; A critique of Nigeria's waste management policy. International Journal of Knowledge, Culture and Change Management,1-38

vii. Blundell,T. (2004). Chemicals in Products: Safe Guarding the Environment and Human Health. Science in Parliament,61(3):3

viii. Dauda M.\&Osita 0.0. (2003). Solid waste management and re-use in Maiduguri, Nigeria, Towards the millenium development goals, 29th WEDC International Conference, Abuja, Nigeria, pp.20-23.

ix. DeGroff, A. \&Cargo, M.(2009). Policy Implementation: Implications for evaluation (ed.),Knowledge utilisation, diffusion, implementation, transfer, and translation, New Directions for Evaluation,124:47-60.

x. Egesi O.C.,Ikeuka P.I., Alum-Udensi O., Uchendu U.I.(2016). Status of Solid Waste Management in Umuahia Municipality, Abia State, Nigeria. IIARD International Journal of Geography and Environmental Management,2(1):1-5.

xi. Ezerie H.E., Chima G.N., Ogbonna C.E., Ogbonna C.E., Chibunna J.B. (2017). Municipal Solid Waste Management in Aba, Nigeria: Challenges and Prospects. Environmental Engineering Research, 22(3):231-236.

xii. Federal Ministry of Environment, ENVIRONMENTAL POLICIES 9, (Jan. 30,2014), available at http://environment.gov.ng/index.php/downloads/3-environment-policies. Retrieved 10/07/2021.

xiii. Habiru S., Mohammed A.D., Alhaji H. (2017). Review of Environmental Perception for Successful Waste Management Policy Implementation. International Journal of Business and Administration Research Review,3(20):96-102

xiv. Hoornweg Daniel, Bhada-Tata, P. (2012). What a waste: a global review of solid waste management. Urban development series. Knowledge paper No. 15 (1) Washington dc:World Bank.

xv. Imam, A., Mohammed, B., Wilson, D.C., Cheeseman, C.R.(2008). Solid waste management in Abuja, Nigeria. Waste Management, 28(2):468-472.

xvi. Imoh, U. \& Emmanuel, U. (2011). Domestic Solid Waste Management in a Rapidly Growing Nigerian City of Uyo. Journal of Human Ecology, 36(3): 229-235.

xvii. Johanna K., Peder S., Sigurd S., Collen H., Mark K., Tim F., (2017). Metropolitan Solid Waste Management Policy Plan 2016-2036. Minnesota Pollution Control Agency. Document number; w-sw7-21

xviii. Maduabuchi M.N. (2018). Assessment of Solid Waste Management in Ikwuano Local Government Area of Abia State, South Eastern Nigeria. Journal of Environment and Waste Management, Vol. 5(2): 275-280

xix. Nduka I,Nwosu U.M., Eke R.A. (2013). Studies on Solid Waste Disposal in Aba, Nigeria, with recommendations for a sustainable sanitary solid waste disposal system. International Journal for Environmental Health and Human Development, 14(2): 42-53.

xx. Oghogho M. \&Temitayo, A. (2011). Nigeria: Environment Law In Nigeria, MONDAQ. Available at http://www.mondaq.com/article. Retrievd 8/07/2021

xxi. Ogwueleka T.C. (2009). Municipal solid waste characteristics and management in Nigeria. Iran J. Environ. Health Sci. Eng., 6(3):173-180

xxii. Olufunmilayo I., Ndububa, Alexander O. (2019). Effect of Selected Electronic Waste Dump Sites on Quality of Surrounding Water Bodies in Abuja, Nigeria. FUOYE Journal of Engineering and Technology,4(2):1-7.

xxiii. Schubeler, P., Wehrle K., Christen J.(1996). Urban Management and Infrastructure: Conceptual Framework for Municipal Solid Waste Management in Loe-income Countries, UNDP/UN-CHS (Habitat)/World Bank/SDC Collaborative Programme on Municipal Solid Waste management in Low-Income Countries. Working Paper, N0 9

xxiv. Shehu, K., Bashir A., Mubi A.M. (2018). Implication of Ineffective Policy Implementation for Community Participation on Waste Management in Bauchi State, Nigeria. FUTY Journal of the Environment, 12(1):1-11.

xxv. Slack R.J., Voulvoulis N.(2005) Household hazardous waste in municipal landfills: contaminants in leachate. Science of the Total Environment, 337(1-3):119-137. 
xxvi. United State Environmental Protection Agency (USEPA,2014). Municipal Solid Waste. Available at www.epa.gov/epawaste/nonhaz/municipal/in dex.htm Retrieved 12/07/2021

xxvii. Warren, P. (2014) Demand-Side Management Policy: Implementation and Success, University College London, London, UK. Available at http://www.iepec.org/conf-docs/papers/2014/peter\%20Warren.pdf. Retrieved $10 / 07 / 2021$.

xxviii. World Health Organisation. (2019) Cholera annual report. Available at

https://apps.who.int/iris/bitstream/10665258764/1/WER9;477-4987.PDF. Retrieved 09/08/2021. 